\title{
EXAMINATION OF WHEY DE-FATTING BY ENHANCED MEMBRANE FILTRATION
}

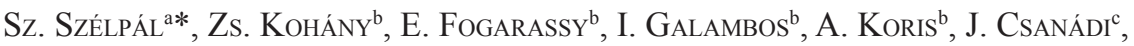 \\ Gy. VATAI ${ }^{\mathrm{b}}$ and C. HODÚR ${ }^{\mathrm{a}}$

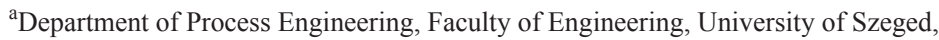 \\ H-6725 Szeged, Moszkvai krt. 5-7. Hungary \\ ${ }^{\mathrm{b}}$ Department of Food Engineering, Faculty of Food Science, Corvinus University of Budapest, \\ H-1118 Budapest, Ménesi út 44. Hungary \\ ${ }^{\mathrm{c}}$ Department of Food Engineering, Faculty of Engineering, University of Szeged, \\ H-6725 Szeged, Moszkvai krt. 5-7. Hungary
}

(Received: 10 April 2014; accepted: 2 July 2014)

\begin{abstract}
The largest quantities of by-products of dairy processing originates from the cheese making. Whey proteins are used for animal feeding and human nutrition as well, for example in dry soups, infant formulas, and supplements. The fat components of the whey might impair its use. The aim of our experiments was to investigate the separation of the lipid fraction of whey. The microfiltration is said to be a gentle and energy efficient method for this task. During the measurements $0.2 \mu \mathrm{m}$ microfiltration membranes were used and the membrane separation was enhanced by vibration, inserting static mixer and air sparging. The de-fatting efficiency, the retention of the whey components, the flux values, and the resistances in different combinations were compared in this paper.
\end{abstract}

Keywords: whey de-fatting, membrane separation, vibration, air sparging, static mixer

Whey contains lactose, vitamins, proteins, minerals and lipids (VAJDA et al., 2013). Whey cream is more salty, tangy, and "cheesy" than ("sweet") cream skimmed from milk, and can be used to make whey butter. The other reason of the de-fatting is the further processing of the whey for dry powder/nutritional supplement (GusTaw, 2008). The de-fatting methods by membranes are new ones. The biggest problem is the low flux and high resistance values during separation. These effects could be mitigated by different methods, i.e. using static mixer, aeration, and vibration (BYRDE \& SAwLey, 1999; AHMAdUn et al., 2009).

Newtonian fluids, such as aqueous solutions, are operating in turbulent flow régime in most industrial applications, but within small diameter tubes or narrow niches the turbulence is not big enough to develop adequate share force to build adequate flux.

The use of static mixers caused higher turbulences in the tube type membranes, resulting in an increase of the flow velocity or the pressure during the membrane process. As the result of higher turbulence, the flux is increased and the operating cost was decreased in tubular membranes with static mixer (Bellhouse et al., 2001; Krstić et al., 2002; Costigan et al., 2002).

The fouling of the membrane is possible to decrease with introduction of gas into the liquid (Cui \& Wright 1996; LABOIRE et al., 1998; CABassud et al., 2001). The introduction of a specific gas - in this case air - directly into the fluid created a two-phase gas/liquid flow, where the bubbles of the gas caused better local mixing, i.e. turbulence. The efficiency of the

* To whom correspondence should be addressed.

Phone: +36-62-546-512; fax: +36-62-546-549; e-mail: szelpal@mk.u-szeged.hu

0239-3006/\$20.00 C 2014 Akadémiai Kiadó, Budapest 
separation is influenced by the position of the membrane (vertical or horizontal) and the direction of the flow (up or down). The aeration method is limited by the gas distribution and the management of this process (DERRADJI et al., 2000). The vibratory shear enhanced process (VSEP) is another possibility to decrease the total membrane filtration resistance (FrAPPART et al., 2008; KERTÉsz et al., 2010). The shears stress at the membrane surface can be increased by varying the frequency of the vibratory motor of the module (RAUTENBACH, 1997; HoDÚR et al., 2009).

Based on the previous statements, the aim of the investigations in this paper was to study the flux and fat retention improvements by different methods as vibration, inserting turbulence promoters (static mixers) as well as air was sparged into ceramic tube membrane.

\section{Materials and methods}

Sweet cheese whey was used for all measurements (Soma Budapest Ltd). Its basic analytical parameters are: fat content: $0.18 \mathrm{w} / \mathrm{w} \%$, protein content: $0.33 \mathrm{w} / \mathrm{w} \%$, lactose content: $2.61 \mathrm{w} / \mathrm{w} \%$, total solids: $3.72 \mathrm{w} / \mathrm{w} \%$, and total protein content: $0.47 \mathrm{w} / \mathrm{w} \%$. These basic parameters were measured by Bentley B150 milk analyser equipment.

The air injection and/or static mixing method were implemented by tubular ceramic membrane with 0.2 micrometer average pore size. The tubular membrane was $0.25 \mathrm{~m}$ long and had an internal diameter of $0.007 \mathrm{~m}$. The applied static mixer was a $0.25 \mathrm{~m}$ long Helix type metal static mixer (produced by StaMixCo Ltd.) with a pitch of $0.006 \mathrm{~m}$ and an inner radius of $0.00635 \mathrm{~m}$ as illustrated in Fig. 1. This tubular membrane and static mixer were used in special, customised equipment, wherein the air injection was introduced into the equipment before the membrane module. The air injection experiment was performed at 50 , 100 , and $150 \mathrm{l} \mathrm{h}^{-1}$ feed recirculation flow rate, at $0.2 \mathrm{MPa}$ transmembrane pressure, and $20 \mathrm{~h}^{-1}$ air injection flow rate. In all measurements the initial amount of feed was 2 litres of sweet whey. The temperature was kept constant at $30{ }^{\circ} \mathrm{C}$ during the tests.

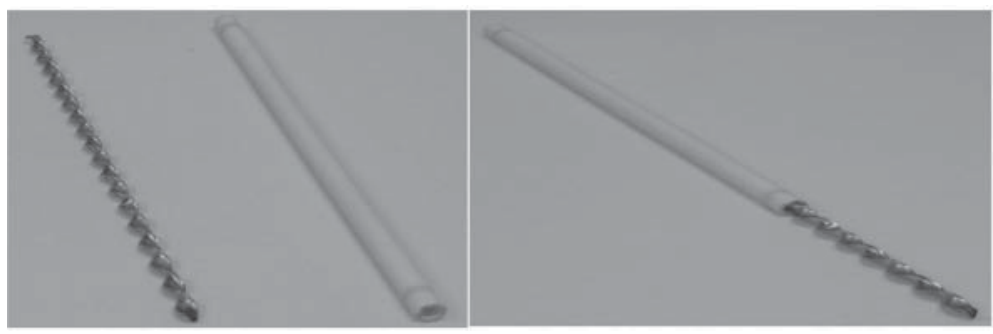

Fig. 1. The Helix type static mixer (HSM) and the ceramic tube membrane (CTM)

Vibratory filtration equipment (VSEP) set marketed by New Logic International Corp. was used at L-mode (L: laboratory methods: the module comprises one disk-shaped membrane with an active filter surface $503 \mathrm{~cm}^{2}$ ). The VSEP system consists of disk-shaped flat-sheet membranes (produced by New Logic Inc. Corp.) attached to a central shaft. The shaft was vibrated a short distance at a frequency of $54 \mathrm{~Hz} .0 .2 \mu \mathrm{m}$ average pore size membrane (made of polyethersulphone) was used during the measurements, at transmembrane pressure of 0.3 MPa. In this equipment the initial amount of feed was 10 litres of sweet whey. 


\section{Results and discussion}

As in our previous experimental research with the same feed (whey), the retention of the fat was less than $50 \%$ at $0.45 \mu \mathrm{m}$ pore size (GASPAR et al., 2008, 2009), since the process following included $0.2 \mu \mathrm{m}$ pore size tubular membranes. As we realized in the above mentioned investigations, the increase in transmembrane pressure only increased the flux until $0.2 \mathrm{MPa}$, on higher pressure values the flux was at constant value or showed a strong decrease (Fig. 2). When the air injection process was used alone, the flux values remained very low; therefore the air injection method in itself is not recommended for separation. When the Helix static mixer was used alone in the equipment under the same operation parameters, the flux showed higher values than the experiments with air injection, but above $0.2 \mathrm{MPa}$ transmembrane pressures, the flux also strongly decreased, so lower transmembrane pressures gave better results.
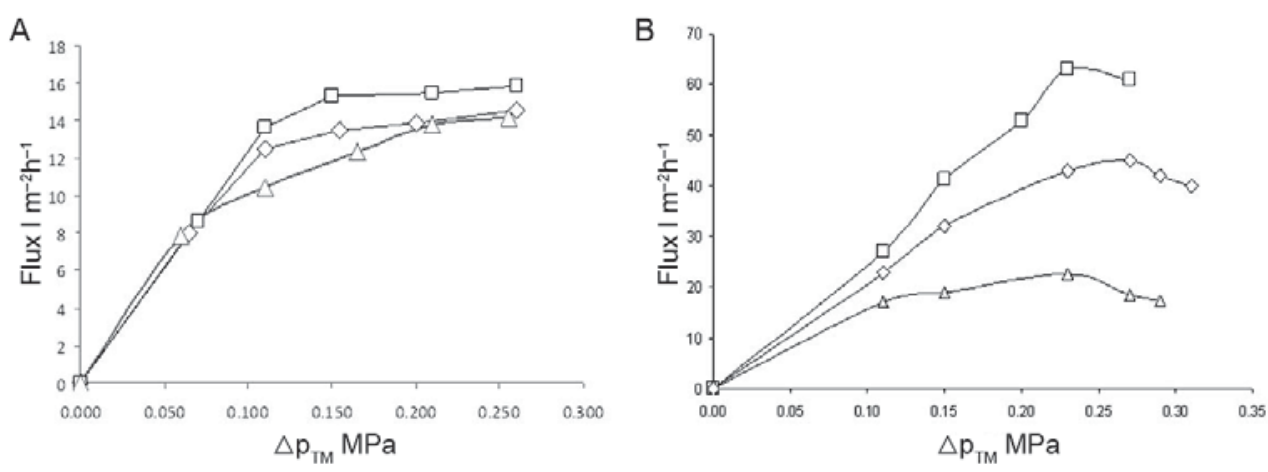

Fig. 2. The changes of whey flux ( $\mathrm{J})$ as a function of transmembrane pressure at different recirculation flow rate A) by air injection and B) by Helix type static stirrer ( $\square-: 1501 \mathrm{~h}^{-1} ; \curvearrowleft-: 1001 \mathrm{~h}^{-1} ; \backsim-: 501 \mathrm{~h}^{-1}$ )

On the basis of these experiments, the whey concentration was carried out with the optimal operation parameters $\left(0.2 \mathrm{MPa}\right.$ transmembrane pressures and at $100 \mathrm{lh}^{-1}$ recirculation flow rate) with and without aeration with and without static mixer, as shown in Fig. 3. The basic flux values in the tubular membrane were $17-181 \mathrm{~m}^{-2} \mathrm{~h}^{-1}$ during the whey concentration process. The flux decreased slightly combined with air injection, but increased up to $301 \mathrm{~m}^{-2} \mathrm{~h}^{-1}$ when the Helix static mixer was used.

When the Helix static mixer was combined with air injection, the flux increased much more, up to $40 \mathrm{l} \mathrm{m}^{-2} \mathrm{~h}^{-1}$, but in case of whey filtration it caused extremely high foaming in the feed tank. 


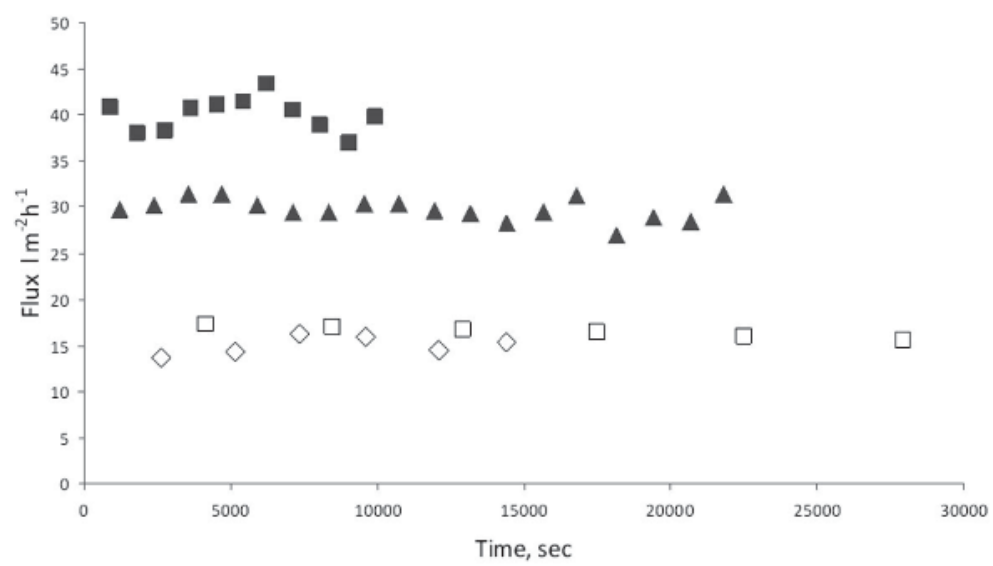

Fig. 3. The Flux $\left(1 \mathrm{~m}^{-2} \mathrm{~h}^{-1}\right)$ values as a function of time (sec) at transmembrane pressure of $0.2 \mathrm{MPa}(\diamond: \mathrm{AS}$ : air sparging; $\mathbf{m}$ : AS: air sparging; + HSM: helix-type static mixer; $\boldsymbol{\Lambda}$ : HSM: helix-type static mixer; $\square$ : CTM: ceramic tube membrane)

Figure 4 presents the effect of different process arrangements on the retention. The static mixer has a slight decreasing effect on the retention of protein and lactose, but the total solid retention increased slightly. Only the fat retention increased significantly by using the static mixer; the maximum value was measured at TMP: $0.2 \mathrm{MPa}$ and $\mathrm{q}_{\mathrm{v}}: 150 \mathrm{l} \mathrm{h}^{-1}$. As our goal was to minimise the fat content and to keep the other ingredients, it is clearly seen from the measurements that the $0.2 \mu \mathrm{m}$ pore size tubular membrane with static mixer is the best solution from the applied arrangements. From these results it is also obvious that inserting the Helix type static mixer improved the fat retention, holding constant the retention of other components at $150 \mathrm{l} \mathrm{h}^{-1}$ volumetric recirculation rate, which means $2.1 \mathrm{~m} \mathrm{~s}^{-1}$ flow rate.

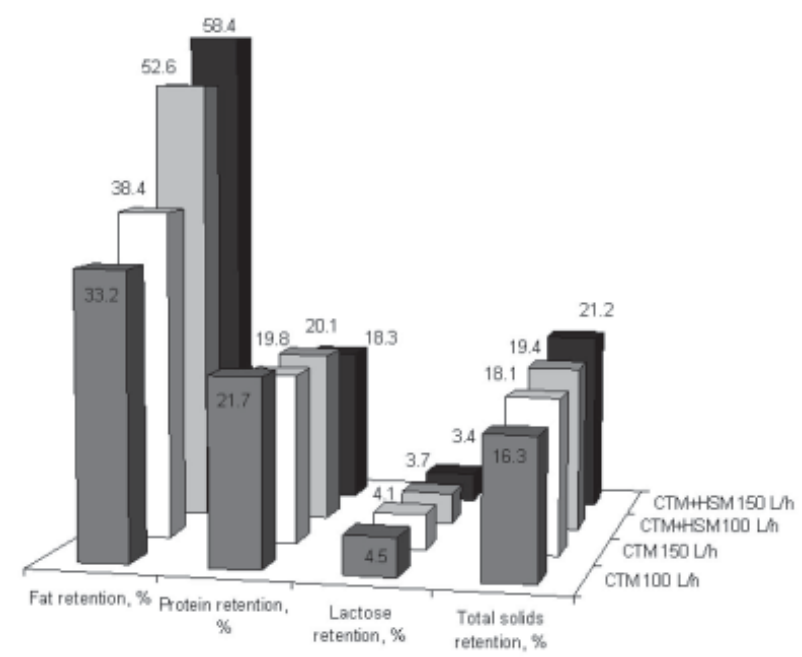

Fig. 4. The retention values (R) of the different components measured in $0.2 \mu \mathrm{m}$ pore size Ceramic Tube Membrane with (CTM+HSM) and without static mixer at a transmembrane pressure of $0.2 \mathrm{MPa}$ (匹: CTM $1001 \mathrm{~h}^{-1} ;$ : CTM + HSM $1001 \mathrm{~h}^{-1}$; $\square:$ CTM $1501 \mathrm{~h}^{-1}$; $:$ CTM + HSM $1501 \mathrm{~h}^{-1}$ ) 
The vibratory shear enhanced membrane filtration was studied with a $0.2 \mu \mathrm{m}$ pore size microfiltration membrane at $0.3 \mathrm{MPa}$ transmembrane pressure at zero and $54 \mathrm{~Hz}$ frequency. The flux increased three times by using vibration $(54 \mathrm{~Hz})$ as it is shown in Fig. 5. What is also very important, this high permeate flux ratio has been kept during the more than 3 hours of whey concentration, while the viscosity of the retentate increased.

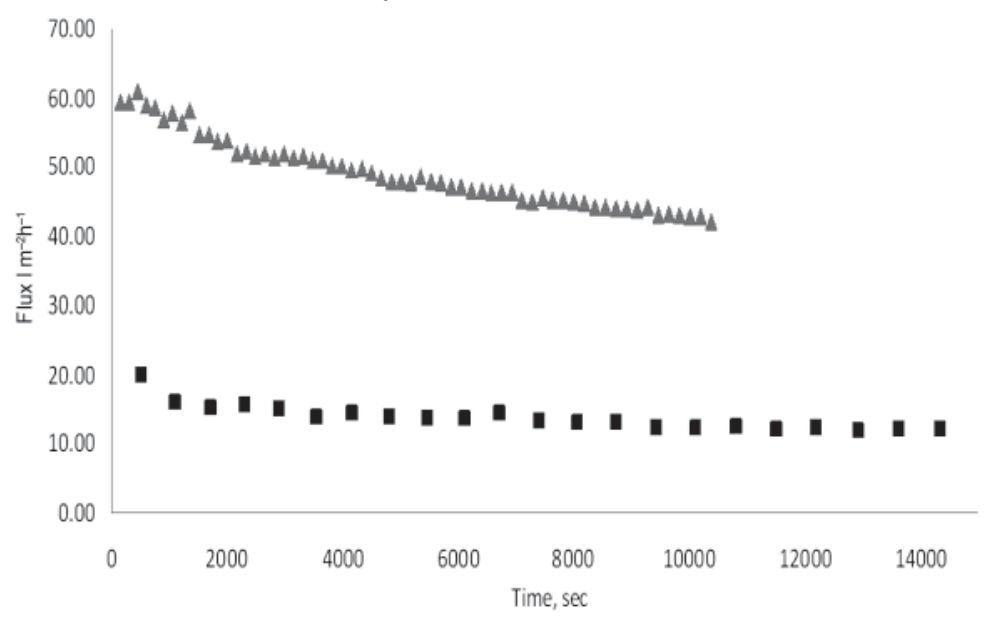

Fig. 5. The flux $\left(1 \mathrm{~m}^{-2} \mathrm{~h}^{-1}\right)$ values as a function of time (sec) by vibrated and non-vibrated methods ( $\Delta: 54 \mathrm{~Hz}$ vibration; $\mathbf{\bullet :} 0 \mathrm{~Hz}$ vibration)

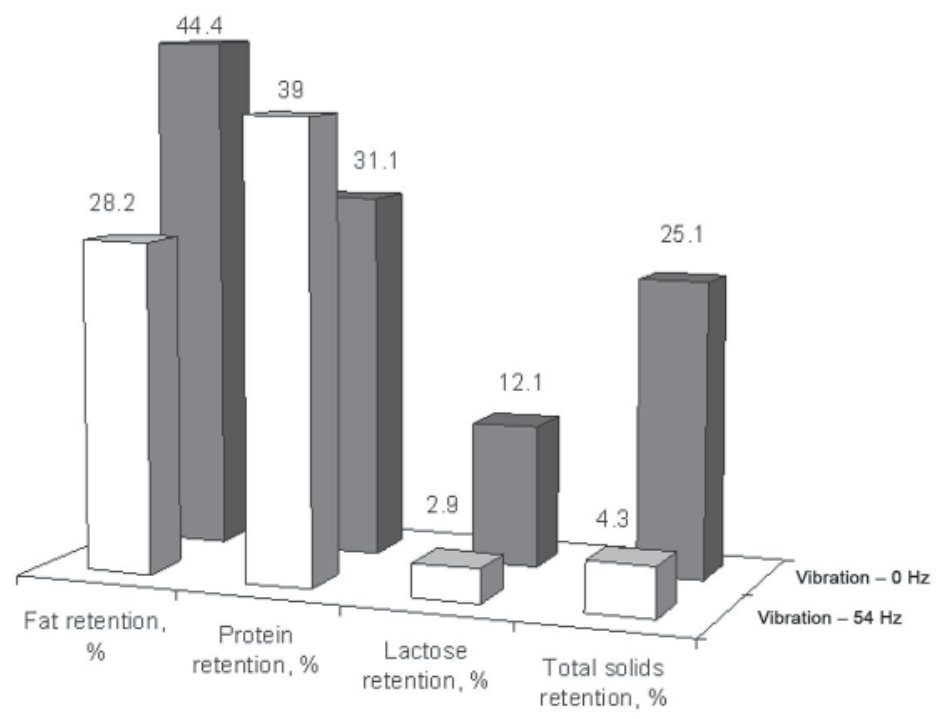

Fig. 6. The retention values of most important components of whey measured in $0.2 \mu \mathrm{m}$ pore size flat-sheet membrane ( $\square$ : vibration $-54 \mathrm{~Hz}$; $\mathbf{m}$ : vibration $-0 \mathrm{~Hz}$ ) 
Using the VSEP technique, the significant flux improvement has not been followed by fat retention improvement, as it can be seen in Fig. 6. This low fat and high protein retention can be explained by the phenomenon that flexible fat globules moved into the capillaries of the membrane under pressure, and due to their sizes (which range from $0.1-10 \mu \mathrm{m}$ with a mean diameter around 3.5 micrometers) they get stuck inside the membrane capillaries. The retention values of fat and protein components were increased by the fouled pores.

To understand the flux improvement in case of static mixer and vibrations, the resistance in series model has been used. The resistance parameters of separations explained the measured differences in case of different arrangements with static mixers (Fig. 7). The total resistance values are already an order of magnitude smaller in case when the static mixer was used, due to less fouling of the membranes, as well as smaller gel layer resistance.

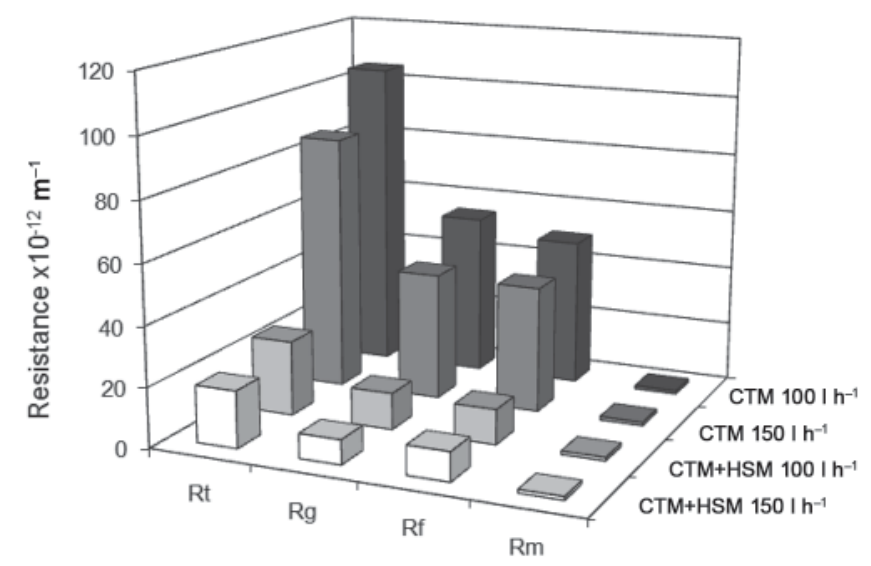

\begin{tabular}{|c|c|c|c|c|}
\hline & Rt & $\mathrm{Rg}$ & Rf & $\mathrm{Rm}$ \\
\hline 口CTM+HSM $150 \mathrm{I} \mathrm{h}^{-1}$ & 19.06 & 8.2 & 9.7 & 1.16 \\
\hline 口CTM+HSM $100 \mathrm{I} \mathrm{h}^{-1}$ & 25.06 & 12.2 & 11.7 & 1.16 \\
\hline 口CTM $150 \mathrm{I} \mathrm{h}^{-1}$ & 86.26 & 42.8 & 42.3 & 1.16 \\
\hline 口CTM $100 \mathrm{I} \mathrm{h}^{-1}$ & 105.16 & 54.5 & 49.5 & 1.16 \\
\hline
\end{tabular}

Fig. 7. Resistances of the ceramic tube membrane (CTM) separation with and without Helix static mixer (HSM) in case of whey separation. $\mathrm{MPa}$

(匹: CTM $1001 \mathrm{~h}^{-1} ;$ : CTM $1501 \mathrm{~h}^{-1} ;$ : CTM + HSM $1001 \mathrm{~h}^{-1} ; \square:$ CTM + HSM $1501 \mathrm{~h}^{-1}$ )

From the resistance values we could conclude that there was significant difference between the gel layer and fouling resistances, which caused the total membrane resistance differences in case of vibrated and non-vibrated systems as illustrated in Fig. 8. In nonvibrating mode, not only the total resistance value was different, but the ratio of different resistances as well. The flux values were four times lower without vibration, and the total resistance was already one order of magnitude higher; the fouling resistance values were five times higher. The resistance values were decreased by the vibration, therefore the fat molecules were allowed to pass through the membrane pores (Fig. 8). 


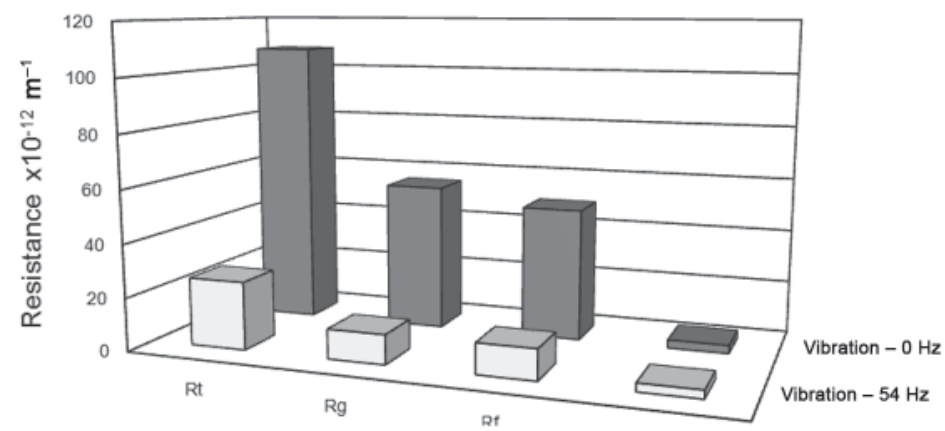

\begin{tabular}{|l|c|c|c|c|}
\cline { 2 - 5 } \multicolumn{1}{c|}{} & $\mathrm{Rt}$ & $\mathrm{Rg}$ & $\mathrm{Rt}$ & $\mathrm{Rm}$ \\
\hline QVibration $-54 \mathrm{~Hz}$ & 25.5 & 11.03 & 11.4 & 3.07 \\
\hline QVibration $-0 \mathrm{~Hz}$ & 107.97 & 53.3 & 49.6 & 3.07 \\
\hline
\end{tabular}

Fig. 8. Resistances of the vibrated and non-vibrated microfiltration of whey measured in $0.2 \mu \mathrm{m}$ pore size flatsheet membrane ( $\square$ : vibration - $54 \mathrm{~Hz}$; $\mathbf{m}$ : vibration $-0 \mathrm{~Hz}$ )

\section{Conclusions}

The experiments showed that relatively high retention values were measured with the $0.2 \mu \mathrm{m}$ pore size membranes. Although the Helix type static mixer produced two times higher flux values than the simple tubular membrane, a synergetic effect occurred by using both aeration and static mixer, and the fat retention slightly followed this rising tendency.

The measured flux values were 3 times higher by $54 \mathrm{~Hz}$ vibration than without vibration. The vibratory shear enhanced membrane process showed that not only the retention values of the fat content decreased with vibration, but the protein retention values increased, causing protein loss during the defatting process.

Comparing these methods it can be concluded that separation carried out using tubular membrane $(0.2 \mu \mathrm{m})$ combined with static mixer gave sufficient result regarding defatting, the retention of other components, and flux values as well.

The authors acknowledge the contribution of the MEMFIDA2 program (EUREKA HU 08-1-2010-0010) and the OTKA K105021 program.

This research was supported by the European Union and the State of Hungary, co-financed by the European Social Fund in the framework of TÁMOP-4.2.4.A/ 2-11/1-2012-0001'National Excellence Program'.

\section{References}

Ahmadun, F.R., Pendashteh, A., Abdullah, L.C., Biak, D.R.A., Madaeni, S.S. \& Abidin, Z.Z. (2009): Review of technologies for oil and gas produced water treatment. J. Hazard. Mater., 170, 530-551.

Bellhouse, B.J., Costigan, G., Abhinava, K. \& Merry, A. (2001): The performance of helical screwthread inserts in tubular membranes. Sep. Purif. Technol., 22-23, 89-113. 
Byrde, O. \& Sawley, M.L. (1999): Optimization of a Kenics static mixer for non-creeping flow conditions. Chem. Eng. J., 72, 163-169.

Cabassud, C., Laboire, S., Durand-Bourlier, L. \& Lainé, J.M. (2001): Air sparging in ultrafiltration hollow fibers: relationship between flux enhancement, cake characteristics and hydrodynamic parameters. J. Membrane Sci., $181,57-69$.

Costigan, G., Bellhouse, B.J. \& Picard, C. (2002): Flux enhancement in microfiltration by corkscrew vortices formed in helical flow passages. J. Membrane Sci., 206, 179-188.

CUI, Z.F. \& WRIGHT, K.I.T. (1996): Flux enhancements with gas sparging in downwards crossflow ultrafiltration: performances and mechanisms. J. Membrane Sci., 117, 109-116.

Derradi, A.F., Bernabeu-Madico, A., Taha, S. \& Dorange, G. (2000): The effect of a static mixer on the ultrafiltration of a two-phase flow. Desalination, 128, 223-230.

Frappart, M., JAfFrin, M.Y., Ding, L.H. \& Espina, V. (2008): Effect of vibration frequency and membrane shear rate on nanofiltration of diluted milk, using a vibratory dynamic filtration system. Sep. Purif. Technol., 62, 212221.

Gaspar, I., Koris, A., Csanadi, J. \& Vatai, Gy. (2008): Effect of operating parameters on the retention of whey components using microfiltration. International Conference on Science and Technique in the Agri-Food Business (ICOSTAF 2008), Szeged, Hungary, Book of abstracts: pp. 189-190. ISBN: 963-482-676-8

Gaspar, I., Koris, A., Bekassy-Molnar, E. \& Vatai, Gy. (2009): A model for the microfiltration of whey with ceramic membranes. Proceedings of the conference PERMEA 2009, Prague, Czech Republic, pp. 166. ISBN: 978-80-85009-58-3

Gustaw, W. (2008): Production and rheological properties of whey protein-polysaccharide mixed (composites) gels. Acta Alimentaria, 37, 359-365.

Hodúr, C. Kertész, Sz., CsanÁdi, J., Szabó, G. \& LÁszló, Zs. (2009): Investigation of vibratory-shear enhanced processing system. Progress in Agricultural Engineering Sciences, 5, 97-110.

Kertész, Sz., Törteli, J., LÁszló, Zs., KovÁcsné, V.P., Szabó, G. \& Hodúr, C. (2010): Dairy wastewater purification by vibratory shear enhanced process. Proceedings of the conference PERMEA 2010, Tatranské Matliare, Slovakia, September 4-8, 2010, pp. 48-58; CD-full article, ISBN: 978-80-227-3339-7

Krstić, D.M., Tekić, M.N., Carić, M.D. \& Milanović, S.D. (2002): The effect of turbulence promoter on cross-flow microfiltration of skim milk. J. Membrane Sci., 208, 303-314.

Laboire, S., Cabassud, C., Durand-Bourlier, L. \& Lainé, J.M. (1998): Fouling control by air sparging inside hollow fibre membranes - effect on energy consumption. Desalination, 118, 189-196.

Rautenbach, R. (1997): Membranverfahren, Grundlagen der Modul- und Anlagen-auslegung. Springer-Verlag, Berlin, pp. 60-77.

VajdA, Á., ZeKe, I., JuhÁsz, R., BarTa, J. \& Balla, Cs. (2013): Effect of acid whey concentrate on thermophysical properties of milk-based ice-cream. Acta Alimentaria, 42 (Suppl.), 107-115. 